\title{
Assessment and mapping the sensitive areas to desertification in an insular Sahelian mountain region Case study of the Ribeira Seca Watershed, Santiago Island, Cabo Verde
}

\author{
Jacques De Pina Tavares ${ }^{a}$, ${ }^{\text {, Isaurinda Baptista }}{ }^{\mathrm{a}}$, António J.D. Ferreira ${ }^{\mathrm{b}}$, Philippe Amiotte-Suchet ${ }^{\mathrm{c}}$, \\ Celeste Coelho ${ }^{\mathrm{d}}$, Samuel Gomes ${ }^{\mathrm{a}}$, Regla Amoros ${ }^{\mathrm{a}}$, Eduardo Amarildo Dos Reis ${ }^{\mathrm{a}}$, Adriano Furtado Mendes ${ }^{\mathrm{a}}$, \\ Lenira Costa ${ }^{a}$, Jailson Bentub ${ }^{\mathrm{e}}$, Larissa Varela ${ }^{\mathrm{f}}$
}

a Instituto Nacional de Investigação e Desenvolvimento Agrário (INIDA), CP 84 Praia, Cape Verde

b Escola Superior Agrária de Coimbra, P-3040-316 Coimbra, Portugal

' Université de Bourgogne, Faculté des Sciences de la Terre, Unité Mixte de Recherche (UMR) - Biogéosciences, Dijon, France

' Universidade de Aveiro, Portugal

e General Agriculture Direction of the Ministry of Rural Development, Cape Verde

${ }^{\mathrm{f}}$ Municipality of São Lourenço Dos Órgãos, Santiago Island, Cape Verde

\section{A R T I C L E I N F O}

\section{Article history:}

Received 14 February 2013

Received in revised form 7 October 2014

Accepted 8 October 2014

Available online 11 November 2014

\section{Keywords:}

Cabo Verde

Desertification

Indicators

Stakeholders' knowledge

Assessing and mapping

\begin{abstract}
A B S T R A C T
This paper presents the assessment and mapping of the Ribeira Seca catchment, an insular Sahelian mountain region sensitive to desertification, located on the island of Santiago, Cabo Verde. Desertification is a threat to the global environment, representing a serious ecological problem in Cabo Verde. To successfully combat desertification, an evaluation of desertification consequences is required and the building of cartography of the sensitivity for arid and semi-arid ecosystems is required as a first step. The MEDALUS model was the basis for this study in which six quality indicators were used: climate, soil, vegetation, land management, erosion and social factors. Several parameters were defined for each indicator with weights varying between 1 (very low) and 2 (very high). The geometric mean of each of the six quality indicators was employed to produce a map of areas sensitive to desertification. The results of this study show that more than $50 \%$ of the watershed show clear evidence of becoming a desertified area.
\end{abstract}

(c) 2014 Elsevier B.V. All rights reserved.

\section{Introduction}

Desertification phenomena result from various processes occurring in arid and semi-arid environments in which water is the major land use limiting factor (Batterbury and Warren, 2001). For the past two decades the concept of desertification in arid, semi-arid and dry subhumid areas was always associated with land degradation as a result of various factors, including climatic variations and human activities (UNCCD, 2000). In this perspective, the intensity of the desertification phenomena was viewed as the degree of vulnerability or the reaction of ecosystems to the impacts of natural or anthropogenic activities (Bouabid et al., 2010). Desertification was generally associated with geo-physical conditions (e.g. soil, slope, vegetation cover) coupled to the inclemency of droughts (Incerti et al., 2007) and water availability (Salvati et al., in press). Since the 1970s, the phenomenon of desertification has been in the forefront of international community concerns due

\footnotetext{
* Corresponding author.

E-mail addresses: jacques.tavares@gmail.com, Jacques.Tavares@docente.unicv.edu.cv (J. De Pina Tavares).
}

to its powerful destabilizing potential of the natural environment and human society (Perini et al., 2009). Several methods were used to evaluate the desertification process such as mathematical models, parametric equations, remote sensing, direct observation and measurements (Sepehr et al., 2007).

In Cabo Verde, desertification is not synonymous with desert advancing, although it may include the encroachment of sand dunes on the land such as at Boa Vista Island. Rather, the persistent degradation of dryland farming caused by hand weeding (systematic cutting of weeds around maize and bean plants, manually with a hoe, two to three times per year) and erosion by water. Droughts are common in Cabo Verde. Rain often falls as tropical downpours, with a high destructive force, causing extensive soil erosion. In Cabo Verde Mannaerts (1986) reports two major causes of desertification: a) the cutting of trees and shrubs used as energy source and b) the short cycle of maize and bean cultivation on marginal lands with steep slopes. At Cabo Verde, with its Sahelian ecosystems, research on the interaction between the physical processes (climate, topography, soil and vegetation) and population dynamics is crucial to better understand the desertification complexity, define areas at risk and to implement 
adequate measures for the enforcement of environmental policies. As in most other semi-arid regions, desertification in Cabo Verde is largely a society-driven problem. To be effectively managed, dryland farming in Cabo Verde requires an understanding of its major ecological problems and its socio-cultural and economic driving forces, which together with climate change, impact land use.

The heterogeneity of cause-effect relationships and the link between desertification factors and human activities are major problems in establishing an efficient methodology to evaluate the desertification process (Rubio and Bochet, 1998). Nevertheless, the importance of these problems was renewed in recent years, considering the role of humans in the external forces such as market, demography, tourism, and agricultural policies, which influence the society-resource system (Brandt et al., 2003). Efficiently combating desertification in dryland farming requires assessment and mapping of desertification in the arid and semi-arid environments. To know the distribution of erosion hazards in a region is of utmost importance in resource and land use planning (Stocking and Elwell, 1973; Sharon, 1990). After the United Nations Desertification Conference held in Kenya in 1977, different approaches and parameters were used to assess and map desertification processes in various countries, namely FAO/UNEP (1984, 1997), MEDALUS (Kosmas et al., 1999), DSPIR-framework (GIWA, 2001), PESERA (Irvine and Cosmas, 2003), WOCAT and LADA (Liniger et al., 2008). Zehtabian et al. (2004) consider that the MEDALUS model, introduced in 1999, has apparent advantages compared to the other approaches. Therefore and because MEDALUS output is of interest to the Cabo Verde case study area, it was chosen for this study.

The objectives of this study are (i) to apply the MEDALUS model to identify sensitive areas to desertification in the Ribeira Seca watershed using GIS tools according to stakeholders' knowledge, (ii) identify the most affected areas by mapping desertification and (iii) to use this information as a basis to propose possible actions to combat desertification in the most affected areas.

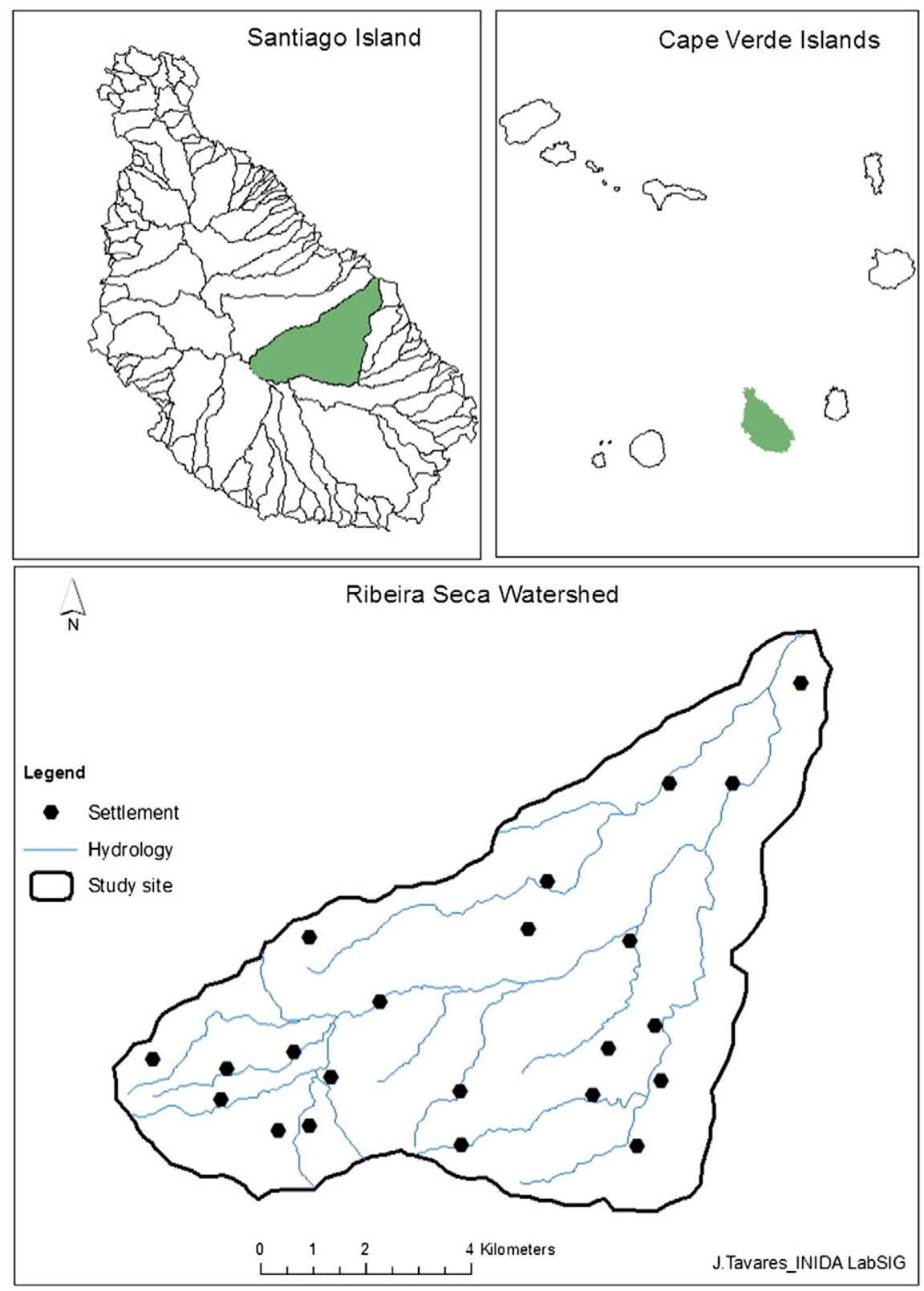

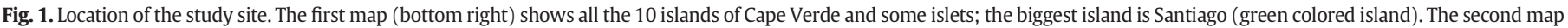

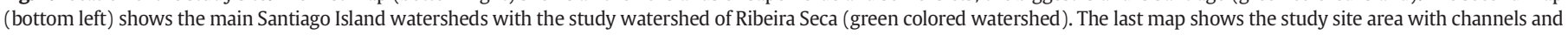
the main settlements. 


\section{Material and methods}

\subsection{Study area}

The ten islands of Cabo Verde Archipelago (Fig. 1) are located about $500 \mathrm{~km}$ off the West African coast. Agriculture is the main activity of the rural population, which accounts for about $46 \%$ of the total population. Rainfall in Cabo Verde and Santiago Island is dependent on the annual movement of the Intertropical Convergence Zone ITCZ (Babau, 1983; Babau et al., 1981; Mannaerts and Gabriels, 2000). Rainfall presents high spatial and temporal variability (Correio, 1998; Mannaerts, 1993; Stern and Dale, 1983). Precipitation is highly influenced by relief and elevation, and varies from less than $100 \mathrm{~mm}$ annually at sea level to over $500 \mathrm{~mm}$ per year in the higher mountain ranges (SanchezMoreno et al., 2014a). The rainfall season lasts two to three months: from August to October when around $300 \mathrm{~mm}$ of rain falls on average. September is generally the wettest month. In general, rainfall is characterized by high intensities, reaching more than $100 \mathrm{~mm} \mathrm{~h}^{-1}$ (Soares, 1985). Daily erosivity can reach values between 200 and $300 \mathrm{KJ} \mathrm{mm} \mathrm{m}{ }^{-2} \mathrm{~h}^{-1}$ for extreme precipitation (Sanchez-Moreno et al., 2014b). Due to the rugged nature of the islands, the poor rain fed practices and eroded relief, it is not easy to find deep soils. In zones with weak slope the soils are more developed and sometimes deeper with horizon differentiation. The lithosols and lithic soils cover most of the islands. The valley bottoms have deep and fertile alluvial soils that are the base of irrigated agriculture. The rugged relief, suffers from the highly variable, scarce but intense rainfall events that have resulted in the predominance of lithosols, regosols and vertisols (Faria, 1970). Soils in Cabo Verde are young and with depths varying between $0.20 \mathrm{~m}$ in high slope areas to 1.00 in the valleys (Sanchez-Moreno et al., 2014c).

In Cabo Verde, the scarcity of arable land and little rainfall strongly limit rain fed agriculture. Arable land covers only $10 \%$ of the total land area, and the production of those lands corresponds only to about $10 \%$ of the national needs. This emphasizes the food insecurity level. The study was conducted in Santiago Island, which has a surface area of $991 \mathrm{~km}^{2}$. It is the main arable region of Cabo Verde, representing more than $56 \%$ of all arable land. More than $90 \%$ of the island inhabitants depend on agriculture. Although rain-fed agriculture is not a priority sector for economic development, agriculture and livestock employ a very broad sector of the population. This study was performed at Ribeira Seca, the largest watershed in Santiago Island $\left(71.5 \mathrm{~km}^{2}\right.$; Fig. 1). Maize and beans are the main crops in this watershed, with a few forested areas in the higher hills (400-1394 m asl) (Bertrand, 1996). Ribeira Seca has four bioclimatic areas: arid, semiarid, sub-humid and mountainous humid areas (Dinis and Matos, 1986) and is the home of about 15,000 people. Several soil and water conservation measures were implemented in the watershed: contour stone walls, contour furrows, terraces, half-moons, green barriers, check dams, and afforestation (Ferreira et al., 2010, 2013; Lopes and Meyer, 1993). Climate alterations, arable land pressure on steep slopes, low soil cover, hand weeding actions, loss of biodiversity, land degradation, flash floods and water erosion symptoms (rills, gullies, offset sedimentation), make the watershed suitable to study desertification.

\subsection{Methodology}

In this study, indicators and parameters that were adapted from Kosmas et al. (1999) to the Cabo Verde context, were calculated with formulas (Table 1) and used to map the sensitive areas to desertification (SAD) in the study site, to better understand desertification. Each indicator has several parameters (Table 2). Such an indicator-based approach has seldom been applied to assess, monitor and evaluate changes in the quality of land resources and desertification in Cabo Verde. At the national, island, municipality and watershed scales, this can help to indicate priorities for policy development and budgetary
Table 1

Stratagem used to collect data in the framework of the study.

\begin{tabular}{lll}
\hline Parameter & Approach & Source of data \\
\hline Rainfall & Formula & INMG $^{\text {a }}$ \\
Evapotranspiration & Turc formula & INMG \\
Aridity & Goessen-Bagnolous formula & INMG \\
Erosivity & Fournier formula & INMG \\
Slope aspect & Field inspection & Field \\
Texture & Laboratory analysis & Field \\
Parent. material & Field inspection & Field \\
Slope gradiente & Clinometer tool & Field \\
Soil depht & Field inspection & Field \\
Organic matter & Laboratory & Field \\
Rock outcrop & Field inspection & Field \\
Plant cover & Field inspection & Field \\
Major land use & Field inspection & Field \\
Land use intensity & Field inspection and & Field and farmers \\
Policy enforcement & farmers inquiry & \\
Soil and water cons. measures & Field inspection and & Field and farmers \\
farmers inquiry & Field inspection and & Field and farmers \\
Soil erosion cons. measures & farmers inquiry & Field inspection \\
Drainage density & Digital topographic map & Field \\
Flood frequency & Map \\
Impervious area & Farmers inquiry & \\
Old age index & Field inspection & Farmers \\
Population density & Formula & Field \\
& Formula & INE \\
\hline b & & City Hall data \\
& and INE \\
\hline
\end{tabular}

a Geophysic and Meteorology National Institute.

b Statistic National Institute data.

allocation by governments, local governments (municipalities), NGOs and rural development projects, providing a proper foundation for policy formation and decision-making on matters affecting land resources at all scales and levels (Pieri et al., 1995). To refine the parameter selection and number of parameters used, this research was largely based on the results matched at three workshops in the framework of the implementation of the DESIRE project in the watershed of Ribeira Seca. These three workshops were a real platform for exchanging experiences and knowledge among farmers, NGOs, local associations of farmers, municipality technicians, researchers and manager delegations of the MDR (Ministry of Rural Development). The water and biomass cycles were widely analyzed and discussed among the different actors in rural development during the first stakeholder workshop. 103 target points were sampled (Fig. 2) according to the manual for describing land degradation indicators (Kosmas et al., 1999). The target sites were selected from the 22 main settlements and the topography complexity of the watershed.

The following indicators of the physical environment, land management and social characteristics were used to define SAD: (a) climate, (b) soils, (c) vegetation, (d) land management, (e) erosion and (f) social indicators. Excel and ArcGIS 9.2 software was used to respectively calculate and map each quality indicator. Finally the SAD was calculated used ordinary Kriging method after interpolation by the spatial analyst tool. As outlined in Fig. 3, each indicator is constructed from several parameters, which are combined to obtain a quality indicator using the following general formula:

Quality indicator

$$
=\left(\text { Parameter }_{1}^{*} \text { Parameter }_{2}^{*} \text { Parameter }_{3}^{*} \ldots{ }^{*} \text { Parameter }_{\mathrm{n}}\right)^{1 / \mathrm{n}} \text {. }
$$

In this equation each quality indicator is based on parameters that are scored as very high, high, moderate, low or very low (score values ranging from 1 (very high) to 2 (very high)), where ' $n$ ' equals the number of parameters. 
Table 2

Structure of range and weight index of each parameter according to the 6 indicators.

\begin{tabular}{|c|c|c|c|}
\hline Indicator & Parameter & Range & W.I. \\
\hline \multirow[t]{22}{*}{ Climate } & \multirow[t]{4}{*}{ Rainfall (mm) } & $<280$ & 2 \\
\hline & & $280-650$ & 1.8 \\
\hline & & $650-1000$ & 1.5 \\
\hline & & $>1000$ & 1 \\
\hline & \multirow{5}{*}{$\begin{array}{l}\text { Evapotranspiration } \\
(\mathrm{mm})\end{array}$} & $>1500$ & 2 \\
\hline & & $1200-1500$ & 1.8 \\
\hline & & $800-1200$ & 1.7 \\
\hline & & $500-800$ & 1.5 \\
\hline & & $<500$ & 1 \\
\hline & \multirow[t]{6}{*}{ Aridity index } & $>160$ & 2 \\
\hline & & $121-160$ & 1.8 \\
\hline & & $100-125$ & 1.7 \\
\hline & & $75-100$ & 1.6 \\
\hline & & $50-75$ & 1.5 \\
\hline & & $<50$ & 1 \\
\hline & \multirow{5}{*}{ Erosivity } & $>160$ & 2 \\
\hline & & $121-160$ & 1.8 \\
\hline & & $91-120$ & 1.7 \\
\hline & & $60-90$ & 1.5 \\
\hline & & $<60$ & 1 \\
\hline & \multirow[t]{2}{*}{ Slope aspect } & SW-SE & 2 \\
\hline & & NW-NE & 1 \\
\hline \multirow[t]{34}{*}{ Soil } & \multirow[t]{6}{*}{ Texture } & Very fine & 2 \\
\hline & & Fine & 1.8 \\
\hline & & Moderate & 1.7 \\
\hline & & Medium & 1.5 \\
\hline & & Coarse & 1.3 \\
\hline & & Very coarse & 1 \\
\hline & \multirow[t]{5}{*}{ Parental material } & Alluv., colluv. & 2 \\
\hline & & Shale, schist & 1.8 \\
\hline & & Basic igneous & 1.7 \\
\hline & & Marl, clay, conglo. & 1.5 \\
\hline & & Sandstone & 1 \\
\hline & \multirow[t]{8}{*}{ Slope gradient (\%) } & $>60$ & 2 \\
\hline & & $35-60$ & 1.9 \\
\hline & & $25-35$ & 1.8 \\
\hline & & $18-25$ & 1.7 \\
\hline & & $12-18$ & 1.6 \\
\hline & & $6-12$ & 1.4 \\
\hline & & $2-6$ & 1.2 \\
\hline & & $<2$ & 1 \\
\hline & Soil depth $(\mathrm{cm})$ & $>15$ & 2 \\
\hline & & $15-30$ & 1.8 \\
\hline & & $30-60$ & 1.7 \\
\hline & & $60-100$ & 1.6 \\
\hline & & $100-150$ & 1.5 \\
\hline & & $<150$ & 1 \\
\hline & Organic matter (\%) & 1 & 2 \\
\hline & & $2-1.1$ & 1.8 \\
\hline & & $2.1-6$ & 1.5 \\
\hline & & $>6$ & 1 \\
\hline & Rock outcrop (\%) & $>60$ & 2 \\
\hline & & $30-60$ & 1.8 \\
\hline & & $10-30$ & 1.7 \\
\hline & & $>10$ & 1.5 \\
\hline & & none & 1 \\
\hline Vegetation & Plant cover (\%) & $>10$ & 2 \\
\hline & & $10-25$ & 1.8 \\
\hline & & $25-50$ & 1.5 \\
\hline & & $50-75$ & 1.2 \\
\hline & & $<75$ & 1 \\
\hline & Major land use & Bare soil & 2 \\
\hline & & Rainfed & 1.8 \\
\hline & & Pasture & 1.6 \\
\hline & & Forest and zone & 1.4 \\
\hline & & Irrigated land & 1.2 \\
\hline & & Forest humid zone & 1 \\
\hline Management & Land use intensity & Agriculture & 2 \\
\hline & & Pasture & 1.5 \\
\hline & & Forest land & 1 \\
\hline & Policy enforcement & No protected $(<5 \%)$ & 2 \\
\hline & $(\%)$ & Low protected (5-25\%) & 1.5 \\
\hline & & Moderate protected (25-75\%) & 1.4 \\
\hline & & Adequate prot. (>75\%) & 1 \\
\hline
\end{tabular}

Table 2 (continued)

\begin{tabular}{|c|c|c|c|}
\hline Indicator & Parameter & Range & W.I. \\
\hline & \multirow[t]{4}{*}{ SWCM } & No measure & 2 \\
\hline & & Inducing vapor adsorption & 1.5 \\
\hline & & Temporary storage of water runoff & 1.4 \\
\hline & & Mulching & 1 \\
\hline & \multirow[t]{4}{*}{ SECM } & No protected $(<5 \%)$ & 2 \\
\hline & & Low protected (5-25\%) & 1.5 \\
\hline & & Moderate protected (25-75\%) & 1.4 \\
\hline & & Adequate prot. (>75\%) & 1 \\
\hline & \multirow[t]{4}{*}{ Drainage (km/km2) } & $<5$ & 2 \\
\hline & & $5-10$ & 1.5 \\
\hline & & $10-20$ & 1.4 \\
\hline & & $>20$ & 1 \\
\hline \multirow[t]{8}{*}{ Erosion } & \multirow[t]{4}{*}{ Flood (n/yr) } & $6-10$ & 2 \\
\hline & & $3-5$ & 1.5 \\
\hline & & $1-2$ & 1.4 \\
\hline & & Less than once every ten years & 1 \\
\hline & \multirow[t]{4}{*}{ Impervious area (ha) } & $>50$ & 2 \\
\hline & & $25-50$ & 1.5 \\
\hline & & $10-25$ & 1.4 \\
\hline & & $<10$ & 1 \\
\hline \multirow[t]{8}{*}{ Social } & \multirow[t]{4}{*}{ Old age index (\%) } & $>20$ & 2 \\
\hline & & $10-20$ & 1.5 \\
\hline & & $5-10$ & 1.4 \\
\hline & & $>5$ & 1 \\
\hline & \multirow[t]{4}{*}{ Population density } & $>300$ & 2 \\
\hline & & $100-300$ & 1.5 \\
\hline & & $50-100$ & 1.4 \\
\hline & & $>50$ & 1 \\
\hline
\end{tabular}

W.I. - weight index.

SWCM - soil and water conservation measures.

SECM - soil erosion conservation measures.

Finally, the desertification sensitivity of the selected areas (SAD) is calculated from the six quality indicators using Eq. (2) (Fig. 3):

$S A D=(S Q i * C Q i * V Q i * M Q i * W R Q i * S o Q i)^{1 / \mathrm{n}}$

where: $S A D$ is desertification sensitive of area; SQi, Soil Quality index; CQi, Climate Quality index; and VQi, Vegetation Quality index; MQi, Management Quality index; ERQi, Erosion Quality index; and SoQi, Social Quality index.

This methodology was recently applied to a similar environment in Dominican Republic where the landscape is rugged and mountainous (Izzo et al., 2013). The choice of parameters is based on stakeholders' knowledge: farmers, local associations of land users, local nongovernmental organizations, technicians of the Ministry of Rural Development and environmental advisors of Municipalities and researchers (Tavares et al., 2013).

\subsubsection{Climate indicator}

The climate indicator is assessed based on parameters affecting water availability for plants such as annual rainfall (R); aridity (A); evapotranspiration (ET); slope aspect; N, S, E, W (Sa) and erosivity (Ero). The latter might inhibit plant growth (Bahreini and Pahlavanravi, 2013; Thornes, 1995). All indicator parameters were categorized into different classes (Table 2). The aridity index was calculated using the Goessen-Bagnolous index (AUA, 2008; Bahreini and Pahlavanravi, 2013; Parvari et al., 2011), according to the manual elaborated by the Agricultural University of Athens (2008) (Eq. (3)) and classified into six classes;

$\underset{i=1}{B G}=\sum_{i=1}^{n}\left(2 t_{i}-P_{i}\right) * k$

In which $B G I$ is the Bagnouls-Gaussen index, $t_{i}$ is the mean air temperature for month i in $0{ }^{\circ} \mathrm{C}, P_{i}$ is the total precipitation for month $\mathrm{i}$ in $\mathrm{mm}$; and $k$ represents the proportion of month during which $2 t_{i}-$ $P_{i}>0$. 


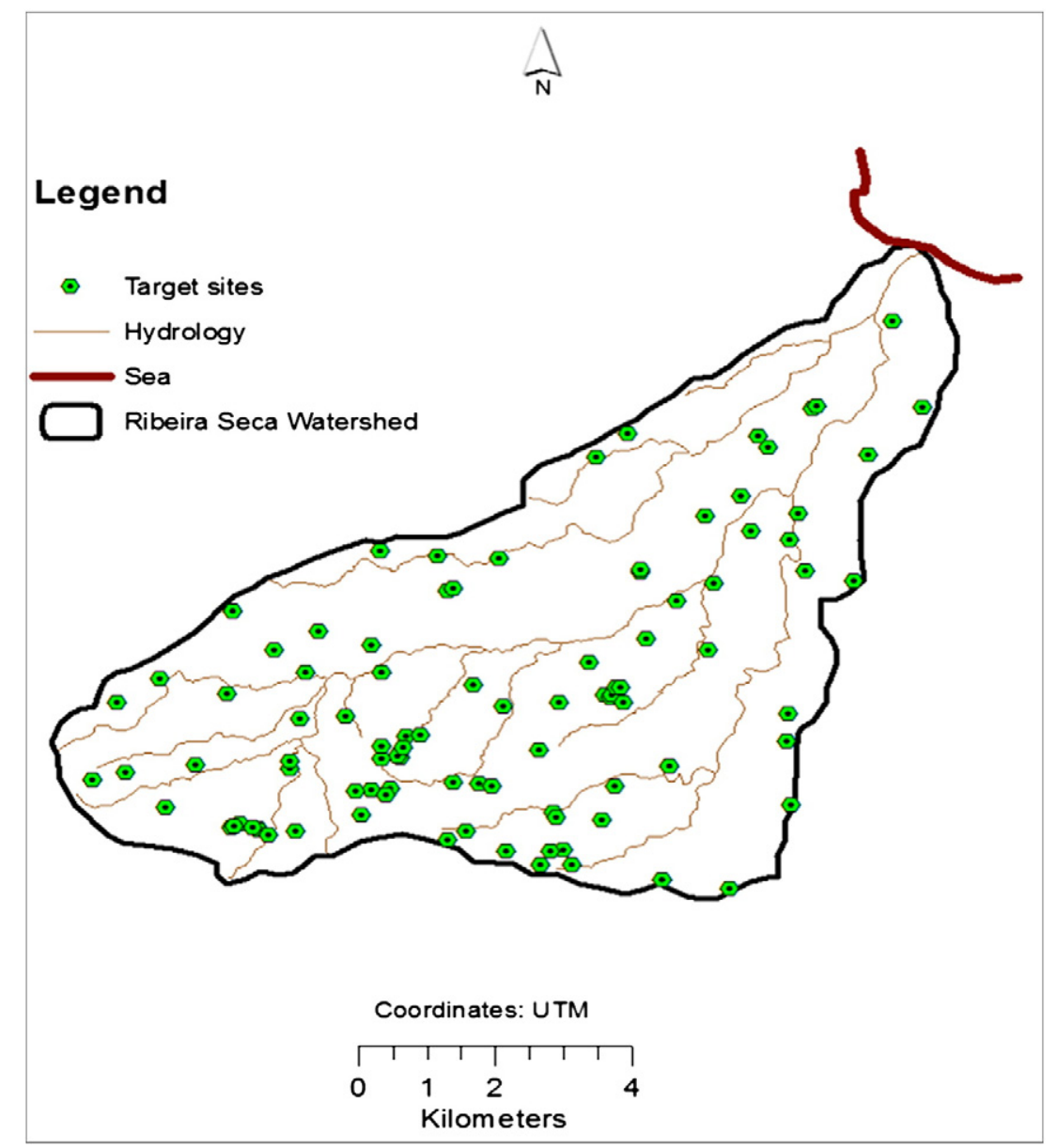

Fig. 2. The 103 target sites with land surveying and soil samples in Ribeira Seca watershed for Santiago Island, Cape Verde.

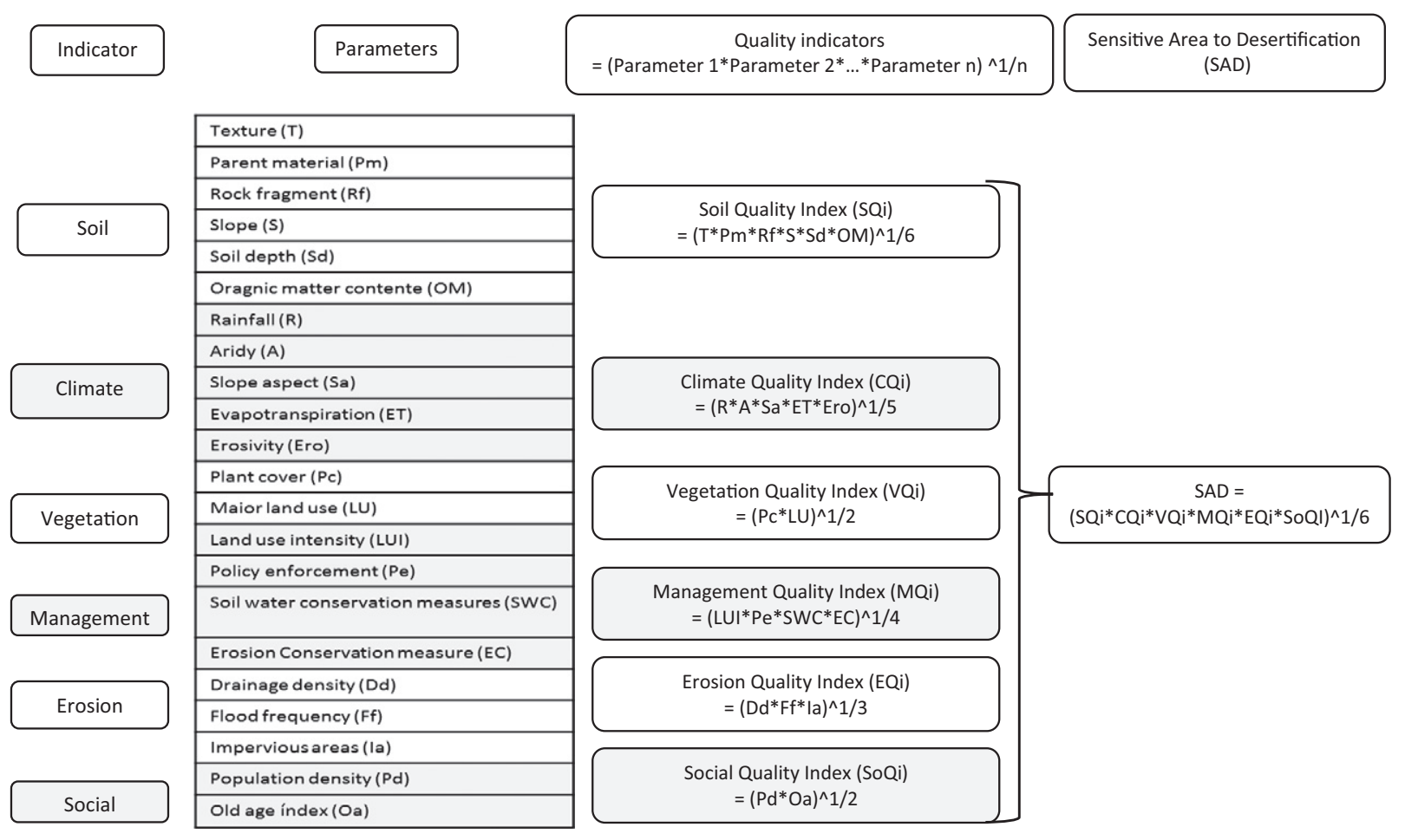

Fig. 3. Outline used to calculate the six indicator qualities and the sensitive areas to desertification (SAD). 
Annual potential evapotranspiration (ET) was calculated using the Turc method (Eq. (4)) and classified into five classes. The Turc method is a relatively simple method compared to other methods (Calanca et al., 2011; Silva et al., 1987).

$$
E=\frac{P}{\sqrt{\frac{0.9+P^{2}}{L^{2}}}}
$$

in which $E$ is annual evapotranspiration ( $\mathrm{mm}$ ), $P$ is annual mean precipitation (mm), $L$ is equal to: $L=300+25 t+0.05 t^{3}$ with $t$ is the annual mean temperature $\left({ }^{\circ} \mathrm{C}\right)$.

Rainfall erosivity depends primarily on rainfall intensity and amount. For calculating erosivity a modified version of the Fournier index (FI) was used (Eq. (5)). It is classified into three classes.

$F I=\sum_{i=1}^{12} P i^{2} / p$

in which $F I$ is the Fournier index, $P i$ is the precipitation total for month $i$, and $p$ is the mean annual precipitation total.

Slope aspect is classified into two classes (Table 2). Finally, the climate quality index (CQi) is obtained through combining the mentioned parameters and using the following formula (Eq. (6)):

$C Q i=(R * A * S a * E T * E r o)^{1 / 5}$.

\subsubsection{Soil indicator}

The role of soil in the desertification process is connected to water availability and soil erodibility. Soil properties such as texture (T), parent material (Pm), exposure rock outcrop (Rf), slope gradient (S), soil depth (Sd) and soil organic matter (OM) on the surface can be defined as soil parameters. Soil texture is related to erodibility and soil capacity to hold water. Availability of water also depends on soil texture and structure. Soils are classified according to their texture in classes, and each textural class has a given range of sand, silt and clay. Parent material is obtained through field inspection at the study site. Different soil types are classified based on lithological and mineralogical properties of rocks and their susceptibility to desertification. Exposure rock outcrop refers to a miscellaneous area which consists of spots of exposures of bedrock and soil, i.e. an (almost) bare area. The rock outcrops are defined according to the percentage cover in four classes. Slope gradient, obtained using a clinometer, is categorized into 8 classes. Soil depth is obtained through field inspection and it is categorized into six classes. Soil organic matter in the surface horizon was determined by chemical analysis in the laboratory using field soil samples. It was categorized in four classes (Table 2). Finally, the Soil Quality Index (SQi) was calculated as the geometric mean of the mentioned parameters using the following equation (Eq. (7)):

$S Q i=(T * P m * R f * E r o * S * S d * O M)^{1 / 7}$.

\subsubsection{Vegetation indicator}

The vegetation quality was assessed based on two parameters: plant cover density (\%) and the major land use (Table 1). The plant cover (Pc) was categorized in five classes. In the study site the main land use (LU) is rainfed agriculture of corn and beans in association and it is categorized into six classes (Table 2). Finally, the Vegetation Quality index (VQi) was calculated as the geometric mean of the mentioned vegetation parameters using the following equation (Eq. (8)):

$V Q i=(P C * L U)^{1 / 2}$.

\subsubsection{Management indicator}

According to land use types, the following groups were determined in the study area: land use intensity (LUI), policy enforcement (Pe), soil and water conservation measures (SWCM) and soil erosion conservation measures (SECM) (Table 2). According to AUA (2008), land use intensity is a function of the degree to which the cultivation of the land is mechanized, fertilizers and pesticides are applied or not. Land use intensity is related to land degradation and desertification processes such as soil erosion, soil structure decline and salinity. Three classes of land use intensity were distinguished: (a) low, (b) medium, and (c) high. Policy enforcement refers to the implementation of existing regulations on environmental protection. The policy enforcement parameter was used to assess the degree of application of specific environmental protection regulations. For example in a cultivated area, some typical management practices to reduce tillage and water erosion are: (i) no tillage or minimum tillage, (ii) tillage of soil in the up-slope direction, (iii) contour farming, (iv) enhancement of vegetation cover. Therefore, the protection of land from soil erosion depends on the effectiveness of the implementation/enforcement of such actions. The information needed depends on the policy under consideration. For example, in the case of terracing protection policy, a relevant piece of information might be the ratio of protected to existing terraces. In the case of extensive agriculture policy, a relevant piece of information might be the percentage of farms (or farmers) or the percentage of area under extensive agriculture. Four classes of policy enforcement were distinguished: (a) adequate ( $>75 \%$ of the land is protected), (b) moderate (25-75\% of the land is protected), (c) low ( $<25 \%$ of the land is protected), and (d) no protection. SWC measures may include the following: mulching, weed control, temporary storage of water runoff in small ponds, management of soil surface for maximum water vapor adsorption, cultivation, etc. Considering that the amount of rain occurring under arid or semi-arid climatic conditions is very low compared to the evapotranspiration rates during the dry period (from February to July), water vapor adsorption becomes one of the most important sources of available water at least to grow annual vegetation. Under such climatic conditions, soil surface characteristics such as surface mulching, and density of the growing plants greatly affect water vapor adsorption and soil water conservation. Land management by (a) reducing the density of the growing vegetation and increasing the soil-atmosphere interface, (b) using surface mulches such as rock fragments or plant residues partially covering the soil surface, and (c) plowing the soil to increase macro porosity can beneficially and significantly affect water vapor adsorption and soil water conservation (AUA, 2008). The existing techniques on soil water conservation were recorded for each target site. The SWC measures were categorized into four classes. SECM includes actions taken to reduce soil erosion caused by various factors such as surface water runoff, tillage operations, wind blowing, etc. Soil erosion control measures may include contour farming, stabilization structures, vegetated waterways, strip cropping, terraces and small water reservoirs. The efficacy of the existing soil erosion control measures is defined in a self-explanatory way as follows: (a) no actions undertaken, (b) low, incomplete protection, less than $25 \%$ of the area protected; (c) moderate, partial protection, $25-75 \%$ of the area protected; (d) adequate, complete protection, $>75$ of the area protected (Table 2). Finally, the Management Quality index (MQi) was calculated as the geometric mean of the mentioned management parameters using the following equation (Eq. (9)):

$M Q i=(L U I * P e * S W C * S E C)^{1 / 4}$.

\subsubsection{Erosion indicator}

The erosion quality indicator was assessed based on factors affecting the flows such as drainage density, flood frequency and impervious area (Table 2). Drainage density is defined as the total length of streams in a drainage basin divided by the area of the basin. This factor was assessed 

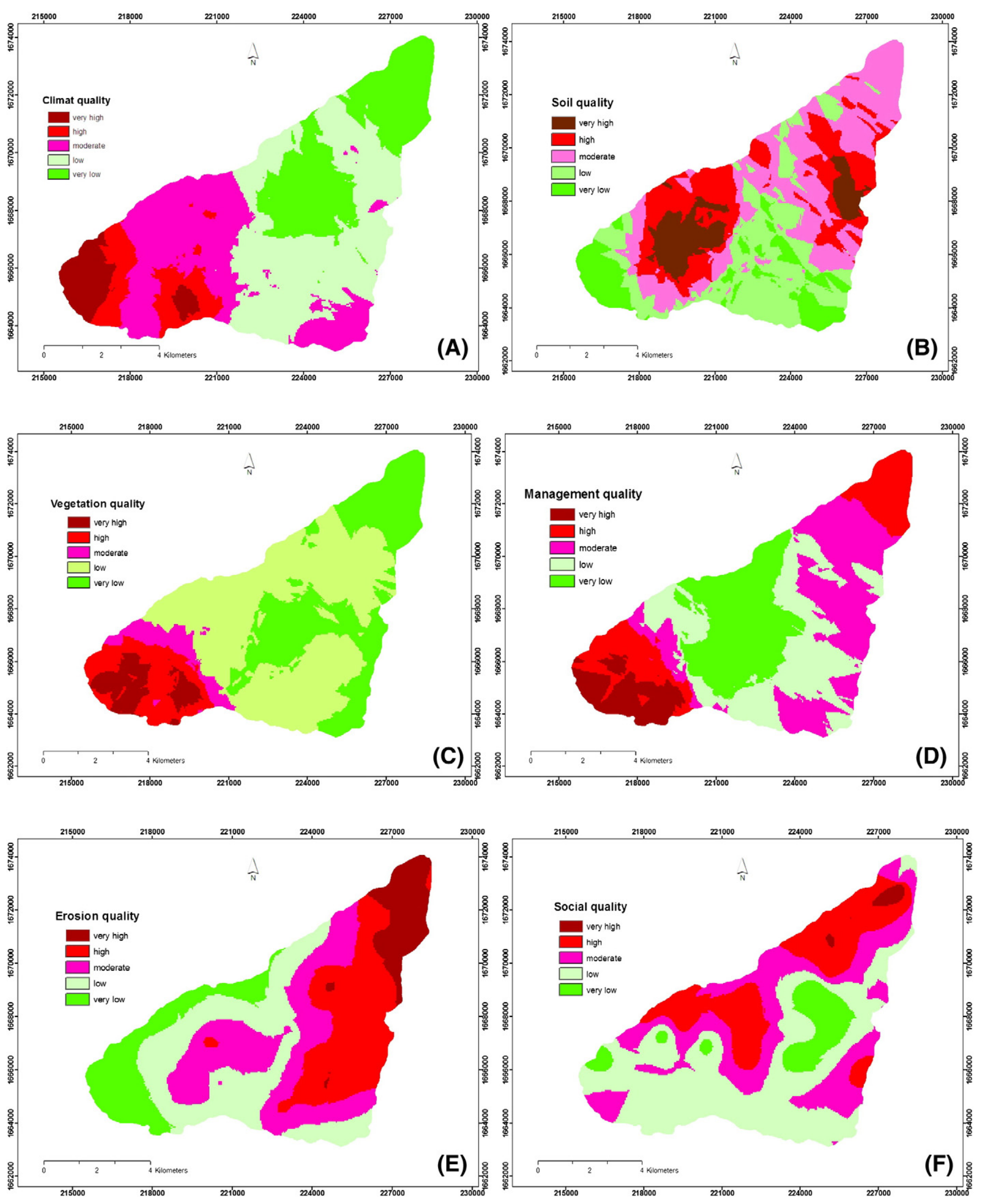

Fig. 4. Indicator quality maps of the study site. Top left and right respectively climate (A) and soil quality (B) indicators. Middle left and right respectively vegetation (C) and management quality (D) indicators. Bottom left and right respectively erosion (E) and social quality (F) indicators. 
using topographic maps of Santiago Island. The following classes of drainage density were used: coarse $\left(<5 \mathrm{~km}\right.$ length per $\mathrm{km}^{2}$ area), medium (5-10 $\left.\mathrm{km} \mathrm{km}^{-2}\right)$, fine $\left(10-20 \mathrm{~km} \mathrm{~km}^{-2}\right)$ and very fine $\left(>20 \mathrm{~km} \mathrm{~km}^{-2}\right.$ ). Flood frequency is the probability of occurrence of damaging floods in an area. A damaging flood is one that destroys or causes severe damage to crops, land or infrastructure. It is estimated quantitatively where data is available, but more often is estimated based on the information given by farmers: Very rare or never: less than once every 10 years or never known to occur, rare: once every 6-10 years, infrequent: once every 3-5 years, frequent every 1 2 years. Impervious surface areas occur when agricultural or other rural land is replaced by the built environment. Soil sealing is the result of the development of housing, industry, transport and other physical infrastructure. It is defined as the surface area sealed in hectares per $10 \mathrm{~km}^{2}$ of territorial surface per 10 years. The following classes were used: low ( $<10$ ha, area sealed in a territorial of $10 \mathrm{~km}^{2}$ per 10 years), moderate (10-25 ha), high (25-50 ha), and very high (>50 ha). Finally, the runoff quality indicator (RQi) was calculated using the following equation (Eq. (10)):

$E Q i=(D d * F f * I a)^{1 / 3}$.

\subsubsection{Social indicator}

Social indicators are linked to desertification process as a result of human actions on the ecosystems. Population density (Pd) and old age index ( $\mathrm{Oa})$ are the main factors used to assess the social quality indicator (SoQi) (Table 2). Population density is closely related to the level of human pressure on natural resources. Population density is defined as the ratio between (total) population and surface (land) area. An alternative definition for population density is the number of persons per unit of area (which may include or exclude cultivated or potentially productive area). The following classes were defined: low $\left(\mathrm{Pd}<50\right.$ people $\left./ \mathrm{km}^{2}\right)$, moderate $\left(50<\mathrm{Pd}>100\right.$ people $\left./ \mathrm{km}^{2}\right)$, high $\left(100<\mathrm{Pd}>300\right.$ people $\left./ \mathrm{km}^{2}\right)$, and very high $\left(\mathrm{Pd}>300\right.$ people $\left./ \mathrm{km}^{2}\right)$. The Old age index emphasizes the strong imbalance between a large number of elderly people in relation to the total population. The old age index $(\mathrm{Oa})$ is the ratio of the population older than 65 years and the total population (Eq. 11). The following classes were defined: low $(R<5)$, moderate $(R=5-10)$, high $(R=10-20)$, and very high $(\mathrm{R}>20)$.

Old age index $=($ population 65 years old/total population $) * 100$.

Finally, the Social Quality indicator SoQi was determined as the geometric mean of the two factors using the following equation (Eq. (12)):

SoQi $=(P d * O a)^{1 / 2}$.

\section{Results and discussion}

The analysis of the six indicators for Ribeira Seca watershed shows that its central part, where the largest rain fed agriculture area is located, is ranked as low to very low environmental quality (Fig. 4). The most important indicators were vegetation, erosion and soil. They present a low to a very low environmental quality in $79.4 \%, 73.8 \%$ and $60.4 \%$ of the watershed area while climate, management and social quality show values of $41.6 \%, 46.4 \%$ and $8.5 \%$ respectively in the low to very low environmental quality segment of the study area (Fig. 5). The quality of the vegetation shows as low because farmers systematically remove the herbaceous layer that develops around the maize using hand-weeding practices and tree pruning before maize and bean planting. This severely limits the development of vegetation to reduce erosion. The low vegetation cover together with intensive rainfall and steep slopes generate large Hortonian overland flow amounts during the wet season. A recent study in Ribeira Seca by Sanchez-Moreno (2012) confirmed this. Overland flow carries an important part of soil and sediments mobilized during hand weeding practices. This activity sharply reduces the quality of arable land soil because each hand weeding action removes the top soil layer where organic matter content is higher.

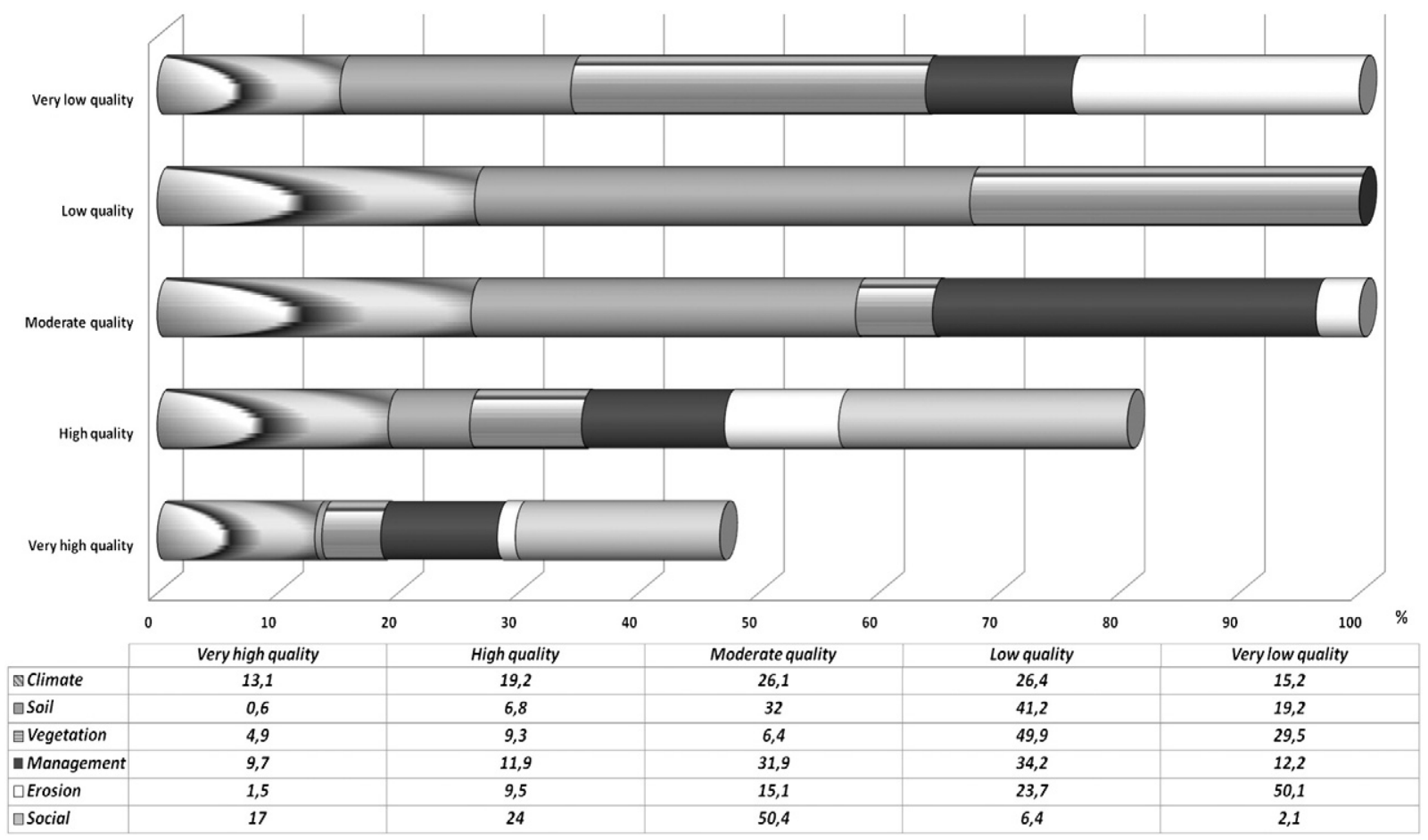

Fig. 5. Distribution of the six indicator qualities and quantification of respective areas (\%). 


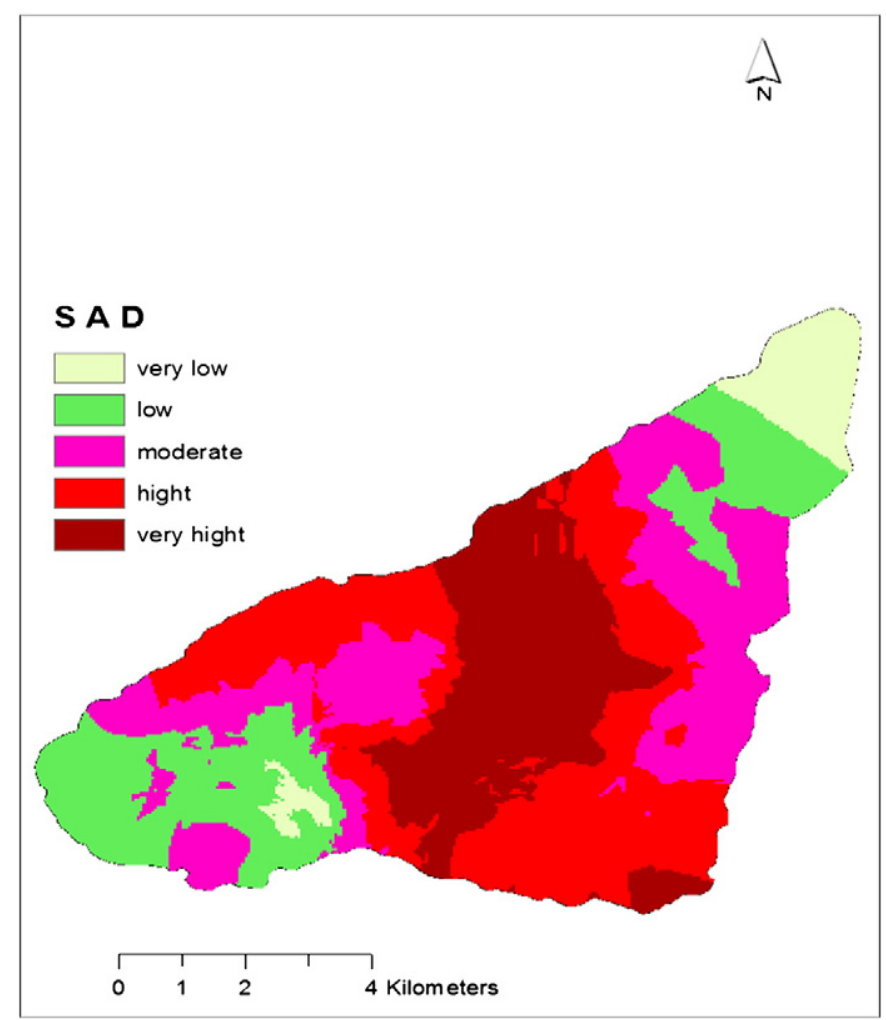

Fig. 6. The distribution of sensitivity areas to desertification in Ribeira Seca watershed.

The distribution of sensitive areas to desertification (SAD) (Fig. 6) shows that the high to very high SAD is also located at the heart of Ribeira Seca and represents $45 \%$ of the area. The extreme east and west of the study site present the larger areas with low sensitiveness to desertification (25.7\%) and slightly less than moderate SAD (29.3\%) (Table 3). The region with high sensitivity to desertification risk is where the vegetation quality is poor. Similar results were reported in Inland Sinai and Eastern desert wadis in Egypt (Gad and Shalaby, 2010).

The areas located in the humid and sub humid mountainous part of the catchment can be treated with green barriers for example with Cajanus cajan (Tavares et al., 2013). The areas located in the semi-arid and arid parts, with high to very high desertification sensitivity can be treated with Aloe vera (Tavares, 2012). Concerning the areas with high desertification sensitivity, it is crucial to improve the education of land users about the consequences of desertification and to try to interest them and the relevant watershed stakeholders such as NGOs, researchers, etc. for adequate measures and strategies to tackle desertification.

We used this methodology and chose the multiplication of parameters because several studies in regions affected by desertification adopted the same approach, in Egypt (Ali and El Baroudy, 2008; Gad and Lotfy, 2008) in Morocco (Bouabid et al., 2010) and in Iran (Honardoust et al., 2011; Parvari et al., 2011; Sepehr et al., 2007).

Table 3

Summarized results of sensitive area to desertification.

\begin{tabular}{lrr}
\hline Desertification & Area & \\
\cline { 2 - 3 } & $\mathrm{km}^{2}$ & $\%$ \\
\hline Very low & 4.0 & 5.6 \\
Low & 14.4 & 20.1 \\
Moderate & 21.0 & 29.3 \\
High & 28.0 & 39.2 \\
Very high & 4.1 & 5.8 \\
SUM & 71.5 & 100.0 \\
\hline
\end{tabular}

Table 4

Indicator and parameter numbers used to assess and map desertification in several regions.

\begin{tabular}{|c|c|c|c|c|}
\hline Indicators & Parameters & Ratio (I/P) & Region used & Reference \\
\hline 4 & 15 & 3.75 & Mediterranean & Kosmas et al. (1999) \\
\hline 4 & 17 & 4.25 & Egypt & Ali et al. (2008) \\
\hline 4 & 15 & 3.75 & Iran & $\begin{array}{l}\text { Bahreini and Pahlavanravi } \\
\text { (2013) }\end{array}$ \\
\hline 4 & 18 & 4.50 & Morocco & Bouabid et al. (2010) \\
\hline 3 & 10 & 3.33 & Egypt & Gad and Lotfy (2008) \\
\hline 6 & 24 & 4.00 & Iran & Sepehr et al. (2007) \\
\hline 6 & 22 & 3.66 & Iran & Honardoust et al. (2011) \\
\hline 6 & 22 & 3.66 & Cape Verde & This study \\
\hline
\end{tabular}

Nevertheless, these authors did not use the same indicators and parameter numbers to map and assess desertification (Table 4). 22 parameters were used to cover the complexity of the Ribeira Seca watershed. The availability of parameters also played an important role in the choice. According to the results, vegetation, erosion and soil indicators have a major impact over SAD in the study site. More than $60 \%$ of the three indicators present values in the low to very low range, with $79.4 \%$, $73.8 \%$ and $60.4 \%$ respectively for vegetation, erosion and soil quality indicators. For further studies about assessment and desertification mapping, it will be interesting to include hand weeding as an erosion indicator parameter, together with rainfall frequency as a climate indicator. The methodology used in the framework of this research is very interesting and versatile, however, its application in a mountainous watershed with several ecological zones (arid, semi-arid, sub humid and humid) requires the choice of several target sites and available data.

\section{Conclusions}

Desertification is one of the great challenges in sustainable rural development in Cabo Verde. This research should be considered a case study concerning methodological and technological approaches for assessment and mapping sensitive areas for desertification (SAD). SAD monitoring was performed using the MEDALUS model supported by field participatory appraisals. Results show that the MEDALUS model is a valuable tool to assess environmental sensitivity to desertification in arid and semi-arid areas like Ribeira Seca-Cabo Verde. It shows that $45 \%$ of the area is at high to very high SAD, $29.3 \%$ at moderate SAD and $25.7 \%$ at low to very low SAD. This allows the identification of areas where the SAD is moderate to very high, and where actions are needed to combat desertification. The approach used in this research can be replicated in other watersheds and mountainous islands like Santo Antão and São Nicolau. The SAD map proved to be a good source of information to help local and national authorities to combat desertification in the Ribeira Seca watershed. We suggest that in order to mitigate desertification in the Ribeira Seca watershed, particularly in the central part of the basin, soil vegetation cover should be improved with less water demanding species, and also controlling of erosion by water should be established by strong stakeholder involvement.

\section{Acknowledgments}

This work was financially supported by the European 6th Framework Research Programme on Desertification - Project DESIRE: Desertification Mitigation and Remediation of Land - a global approach to local solutions carried out at the "Instituto Nacional de Investigação e Desenvolvimento Agrário” (INIDA) - Ministry of Rural Development of Cape Verde (MDR).

Special thanks to the "Instituto Nacional de Meteorologia e Geofísica" (INMG) of Cape Verde in Praia, for providing the meteorological data. 
The authors are indebted to all farmers; local farmer associations; the two City Hall of São Lourenço dos Órgãos, São Domingos and Santa Cruz; and the Organization of Santiago Women (OMS).

We are grateful to Erik van den and the anonymous reviewers for their detailed and useful comments on previous drafts of this paper.

\section{References}

Ali, R.R., El Baroudy, A.A., 2008. Use of GIS in mapping the environmental sensitivity to desertification in Wadi El Natrun Depression, Egypt. Aust. J. Basic Appl. Sci. 2 (1), 157-164.

AUA (Agricultural University of Athens), 2008. Manual for describing land degradation indicators. DESIRE-WB2, (41 pp.).

Babau, M.C., 1983. Evolution de la pluie annuelle de 1885 à 1993 à la station de Praia, île de Santiago, Cap Vert. Document de travail du project Agrhymet: OMM/RAF/78/ 004Technical Report. Organisation Météorologique Mondiale dees Nations Unies, Ministère du Développement Rural, Praia, Cap Vert.

Babau, M.C., Silva, R., Alves, A., 1981. Approches et contraintes climatiques et évaluation des ressources en eau. Document de travailProgramme Agrhymet RAF/CVI/78/004. Praia, Cap Vert.

Bahreini, F., Pahlavanravi, A., 2013. Assess and mapping the environmental sensitivity to desertification (a case study in Boushehr Province, Southwest Iran). Int. J. Agric. Crop Sci. 5 (18), 2172-2183.

Batterbury, S.P.J., Warren, A., 2001. Desertification. In: Smelser, N., Baltes, P. (Eds.), International Encyclopedia of the Social and Behavioral Sciences. Elsevier Press, pp. 3526-3529.

Bertrand, R., 1996. Atlas des ressources naturelles de lîle de Santiago (Cabo Verde). Project PVD-CEE/INIDA/CIRAD-CA 82.

Bouabid, R., Rouchdi, M., Badraoui, M., Diab, A., Louafi, S., 2010. Assessment of land desertification based on the MEDALUS approach and elaboration of an action plan: the case study of the Souss River Basin, Morocco. Land Degradation and Desertification: Assessment, Mitigation 131 and Remediation. Springer Science + Business Media B.V. http://dx.doi.org/10.1007/978-90-481-8657-0_10, (131-145 pp.).

Brandt, J., Geeson, N., Imeson, A., 2003. A desertification indicator system for Mediterranean Europe. DESERTLINKS Project, (www.kcl.ac.uk/desertlinks).

Calanca, P., Smith, P., Holzkämper, A., Ammann, C., 2011. L'évapotranspiration de référence et son application en agrométéorologie. Station de recherche Agroscope Reckenholz-Tänikon ART, 8046 Zurich. Rech. Agronomique Suisse 2 (4), 176-183.

Correio, E., 1998. Condições pluviométricas para a cultura de milho na ilha de Santiago (cabo Verde). Ministério da Ciência e da Tecnologia. Instituto de Investigação Científica Tropical, Lisbos, p. 112

Dinis, A.C., Matos, G.C., 1986. Carta de Zonagem Agro-Ecologica e da Vegetação de Cabo Verde, ilha de Santiago. Garcia de Horta, Ser. Bot. 8, pp. 39-82.

FAO-UNEP, 1984. Provisional Methodology for the Assessment and Mapping of Desertification. FAO, Rome.

FAO-UNEP, 1997. Land Quality Indicators and Their Use in Sustainable Agriculture and Rural Development. FAO, Rome.

Faria, X., 1970. Os solos da ilha de Santiago. Estudos, Ensaios e documentos. Junta de Investigações do ultramar. 157 p., 1 map (1:50000), Lisboa, n.124.

Ferreira, A.J.D., Tavares, J., Baptista, I., Coelho, C.O.A., Reis, A., Varela, L., Bentub, J., 2010. Efficiency of overland and erosion mitigation techniques at Ribeira Seca, Santiago Island, Cape Verde. Surface Runoff and Overland FlowHydrological Science and Engineering Book Series. Nova Science Publishers, New York.

Ferreira, A.J.D., Baptista, I., Tavares, J., 2013. A luta contra a desertificação em Cabo Verde. Riscos Naturais Antrópicos e Mistos. Livro de Homenagem ao Prof. Dr. Fernando Rebelo. Departamento de Geografia, Faculdade de Letras da Universidade de Coimbra Portugal, pp. 697-712.

Gad, A. Lotfy, I., 2008. Use of remote sensing and GIS in mapping the environmenta sensitivity areas for desertification of Egyptian territory. e Earth Discuss. 3, 41-85.

Gad, A., Shalaby, A., 2010. Assessment and mapping of desertification sensitivity using remote sensing and GIS. Case study: inland Sinai and eastern desert wadies. US-Egypt Workshop on Space Technology and Geo-information for Sustainable Development, Cairo, Egypt 14-17 June 2010, p. 6.

GIWA (Global International Water Assessment), 2001. DPSIR Framework for State of Environment Reporting (Driving Forces-Pressures-State-Impacts-Responses). European Environment Agency.

Honardoust, F., Ownegh, M., Sheikh, V., 2011. Assessing desertification sensitivity in the northern part of Gorgan Plain, southeast of the Caspian Sea, Iran. Res. J. Environ. Sci. (ISSN: 1819-3412) 5 (3), 205-220. http://dx.doi.org/10.3923/rjes.

Incerti, G., Feoli, E., Giovacchini, A., Salvati, L., Brunetti, A., 2007. Analysis of bioclimatic time series and their neural network-based classification to characterize drought risk patterns in south Italy. Int. J. Biometeorol. 51, 253-263.

Irvine, B., Cosmas, C., 2003. PESERA (Pan-European Soil Erosion Risk Assessment Model), (35 pp.).
Izzo, M., Araujo, N., Aucelli, P.P.C., Maratea, A., Sánchez, A., 2013. Land sensitivity to desertification in the Dominican Republic: an adaptation of the ESA methodology. Land Degrad. Dev. 24, 486-498. http://dx.doi.org/10.1002/ldr.2241.

Kosmas, C., Kirkby, M., Geeson, N., 1999. The MEDALUS project: Mediterranean desertification and land use. Manual on Key Indicators of Desertification and Mapping Environmentally Sensitive Areas to DesertificationEuropean Commission, Project ENV4 CT 950119 (EUR 18882).

Liniger, H., van Lynden, G., Nachtergaele, F., Schwilch, G., 2008. A Questionnaire for Mapping Land Degradation and Sustainable Land Management. CDE/WOCAT, FAO/ LADA, ISRIC.

Lopes, L.V., Meyer, J., 1993. Watershed management in Cape Verde. Environmental Management vol. 17, No. 1. Springer-Verlag New York Inc., pp. 51-57, (_9 1993).

Mannaerts, C., 1986. Evaluation of Environmental and Socio-Economic Components Related to Land Use in Small Watersheds. F.A.O. U.N.

Mannaerts, C., 1993. Assessment of the transferability of laboratory rainfall-runoff and rainfall soil loss relationships to field and catchment scale. A Study in the Cape Verde Islands. ITC Publication Number 19,p. 202

Mannaerts, C., Gabriels, D., 2000. Rainfall erosivity in Cape Verde. Soil Tillage Res. 55, 207-212.

Parvari, S.H., Pahlavanravi, A., Nia, A.R.M., Dehvari, A., 2011. Application of methodology for mapping environmentally sensitive areas (ESAs) to desertification in dry bed of Hamoun Wetland (Iran). Int. J. Nat. Resour. Mar. Sci. 1 (1), 65-80.

Perini, L., Cecarelli, T., Zitti, M., Salvati, L., 2009. Bio-physical and socio-economic insight desertification in Italy. Ital. J. Agro Meteorol. (3), 45-55.

Pieri, C., Dumanski, J., Hamblin, A., Young, A., 1995. Land Quality Indicators. World Bank, Washington D.C.

Rubio, J.L., Bochet, E., 1998. Desertification indicators as diagnosis criteria for desertification risk assessment in Europe. J. Arid Environ. 39, 113-120.

Salvati, L., Macculi, F., Zitti, M., Toscano, S., 2014. Comparing indexes of intensive agriculture for the assessment of land degradation. Biota, (in press).

Sanchez-Moreno, J.F., 2012. The power of rain: rainfall variability and erosion in Cape Verde, (Dissertation of Ph.D. at the University of Twente-Netherlands-ITC, 95-120 pp.).

Sanchez-Moreno, J.F., Mannaerts, C., Jetten, V., Löffler-Mang, M., 2014a. Rainfall kinetic energy-intensity and rainfall momentum-intensity relationships for Cape Verde. J. Hydrol. 454-455, 131-140.

Sanchez-Moreno, J.F., Mannaerts, C., Jetten, V., Tavares, J., 2014b. Selecting best mapping strategies for storm runoff modeling in a mountainous semi-arid area. Earth Surf. Process. Landforms 39, 1030-1048. http://dx.doi.org/10.1002/esp.3501.

Sanchez-Moreno, J.F., Mannaerts, C., Jetten, V., 2014c. Applicability of satellite rainfall estimates for erosion studies in small offshore areas: a case study in Cape Verde Islands. vol. 121, pp. 365-374. http://dx.doi.org/10.1016/J. CATENA.2014.05.029.

Sepehr, A., Hassanli, A.M., Ekhtesasi, M.R. Jamali, J.B, 2007. Quantitative assessment of desertification in south of Iran using MEDALUS method. Environ. Monit. Assess. 134, 243-254. http://dx.doi.org/10.1007/s10661-007-9613-6.

Sharon, N.G., 1990. Soil Erosion Assessment in the Republic of Cape Verde, West Africa, Using a Geographic Information System. Oregon State University, U.S.A., p. 131

Silva, J.T.N., Herman, M.L.P., Caetano, L.S., Veado, R.W., Silva, A., 1987. Estimativa da evapotranspiração potencial segundo 0 método de Turc e uma analise comparativa desse método com os métodos de Penman e Thornthwaite para o estado de Santa Catarina. GEOSUL - N9 3 - 19 sem,p. 32

Soares, H.C. da S., 1985. Overview of Capverdean agriculture, perspectives in medium and long terms. Revista of Agricultural Research-CEA. Serie A, No. 1: 27-34. São Jorge dos Órgãos, ilha de Santiago, Rep. of Cape Verde.

Stern, R.D., Dale, I.C., 1983. Statistical Methods for Tropical Drought Analysis, Based on Rainfall Data. World Meteorological Organization, Genève (59 pp.).

Stocking, M.A., Elwell, H.A., 1973. Soil erosion hazard in Zimbabwe. Zimb. Agric. J. 70 (4).

Tavares, J., 2012. Aloe vera living barriers. Desire for greener land-options for sustainable land degradation in drylands. DESIRE (Desertification Mitigation and remediation of Land - A Global Approach for Local Solutions)-WOCAT (World Overview of Conservation Approaches and Technologies),pp. 157-160.

Tavares, J., Ferreira, A., Reis, E.A., Baptista, I., Amoroso, R., Costa, L., Furtado, A., Coelho, C., 2013. Appraising and selecting strategies to combat and mitigate desertification based on local and external stakeholder knowledge and global best practices in Cape Verde Archipelago. Land Degrad. Dev. 25, 45-57. http://dx.doi.org/10.1002/ldr.2273.

Thornes, J.B., 1995. Mediterranean desertification and the vegetation cover. In: Fantechi, R., Peter, D., Balabanis, P., Rubio, J.L. (Eds.), EUR 15415 Desertification in a European Context: Physical and Socioeconomic Aspects. Office for Official Publications of the European Communities, Brussels, pp. 169-194.

UNCCD (United Nations Convention for Combating Desertification), 2000. Assessment of the Status of Land Degradation in Arid, Semi-arid and Dry Sub-humid Areas. United Nations Convention to Combat Desertification, Bonn Germany.

Zehtabian, G.H., Ahmadi, H., Khosravi, H., Rafiei Emam, A., 2004. An approach to desertification mapping using MEDALUS methodology in Iran. Desert J. 10, 205-223. 